\title{
BAITUL MAAL WAT TAMWIL LEGALITAS DAN PENGAWASANNYA
}

\author{
Thalis Noor Cahyadi \\ (Praktisi Hukum Syari'ah)
}

\begin{abstract}
As one of the non-bank sharia financial institution, BMT has grown rapidly in Indonesia. But the condition has not been supported by legality of BMT clearly. Until now, there is no regulation for BMT both inform a law and rules under the law, which states directly to existence of BMT. Some experts stated that BMT is same as cooperation in order to BMT subjects to the Law of Cooperation but other experts stated that BMT ran like a bank, so that it can not subjects to the law of cooperation, but must be a bank agrees with the banking laws. The problem is one of many problems founded. Another problem is watching and controlling problems. This paper will discuss about the legality and controlling of BMT.
\end{abstract}

Keywords: BMT, legality, controlling.

\section{Payung Hukum Baitul Maal wat Tamwil (BMT)}

Secara kategoris, lembaga keuangan dibagi menjadi dua jenis yakni lembaga keuangan bank (LKB) dan lembaga keuangan bukan bank (LKBB). Keberadaan LKB dilandasi oleh payung hukum yang jelas berdasarkan peraturan perundang-undangan seperti Undang-undang Nomor 10 Tahun 1998 tentang Perubahan atas Undang-undang Nomor 7 Tahun 1992 tentang Perbankan, Undang-undang Nomor 21 Tahun 2008 tentang Perbankan Syariah serta berbagai Peraturan Bank Indonesia (PBI) yang mengatur aturan teknis Perbankan dan Perbankan Syariah di Indonesia. LKB terdiri dari Bank Umum, Bank Umum Syariah (BUS), Bank Perkreditan Rakyat (BPR), Bank Pembiayaan Rakyat Syariah (BPRS) dan Unit Usaha Syariah (UUS).

Sementara keberadaan LKBB secara nyata lebih banyak berwujud Lembaga Keuangan Mikro (LKM). Pada implementasinya paling tidak ada tiga elemen penting yang terkandung dalam LKM yakni: pertama, menyediakan beragam jenis pelayanan keuangan. Keuangan mikro dalam pengalaman masyarakat tradisional Indonesia seperti lumbung desa, lumbung putih nagari dan sebagainya menyediakan pelayanan keuangan yang beragam seperti tabungan, pinjaman, pembayaran, deposito maupun asuransi.

Kedua, melayani masyarakat miskin. Keuangan mikro hidup dan berkembang pada awalnya memang untuk melayani masyarakat yang terpinggirkan oleh sistem keuangan formal yang ada sehingga memiliki karakteristik konstituen yang khas. Ketiga, menggunakan prosedur dan 
mekanisme yang konstekstual dan fleksibel. Hal ini merupakan konsekuensi dari kelompok masyarakat yang dilayani, sehingga prosedur dan mekanisme yang dikembangkan untuk keuangan mikro akan selalu kontekstual dan fleksibel (Krishnamurti, 2005).

Berdasarkan bentuknya, secara umum LKM dibagi menjadi 3 (tiga) yakni: pertama, lembaga formal seperti bank desa dan koperasi; kedua, lembaga semi formal sepeti Lembaga Swadaya Masyakarat (LSM) atau Organisasi Non Pemerintah (Ornop); dan ketiga, sumber-sumber informal misalnya pelepas uang (Wiyono, 2005).

Selain itu ada pula yang membagi LKM menjadi 4 (empat) golongan besar yakni: pertama, LKM formal, baik bank maupun non bank; kedua, LKM non formal, baik berbadan hukum maupun tidak; ketiga, LKM yang dibentuk melalui program pemerintah; dan keempat, LKM informal seperti rentenir ataupun arisan (Usman dan Suharyo, 2004).

Secara teknis yuridis LKM dapat digolongkan menjadi 2 (dua) yakni LKM Formal dan Informal. LKM Formal adalah LKM yang memiliki landasan hukum dan legitimasi dari instansi yang berwenang sebagaimana diatur dalam peraturan perundang-undangan yang ada. Bentuk dari LKM formal ini antara lain adalah Koperasi dengan segala variannya seperti Koperasi Simpan Pinjam (KSP) dan Koperasi Jasa Keuangan Syariah (KJKS). Keberadaan koperasi diatur dalam Undang-undang Nomor 25 Tahun 1992 tentang Perkoperasian, serta berbagai Paraturan Menteri Koperasi sebagai pedoman teknis perkoperasian.

Adapun LKM Informal dibentuk tanpa ada landasan hukum dan legitimasi dari instansi yang berwenang sebagaimana diatur dalam peraturan perundang-undangan. Bentuk dari LKM ini antara lain Kelompok Swadaya Masyarakat (KSM), LKMS (Lembaga Keuangan Mikro Syariah) dan atau BMT (Baitul Maal wat Tamwil).

Masuknya BMT sebagai bagian dari LKM Informal bukan tanpa alasan, karena memang hingga saat ini eksistensi BMT belum terwadahi dalam payung hukum yang jelas. Ketidakjelasan payung hukum ini ditandai dengan tidak ada satupun regulasi dari tingkat nasional maupun daerah yang mengatur tentang eksistensi dan badan hukum BMT. $\backslash$

Undang-undang Lembaga Keuangan Mikro (LKM) yang disahkan awal Desember 2012 juga tidak memuat tentang BMT. Undang-undang ini justru membahas tentang status badan hukum LKM. LKM dalam undangundang ini boleh memilih badan hukum antara koperasi dan perseroan terbatas, dengan ijin dan pengawasannya akan dikeluarkan oleh Otoritas Jasa Keuangan (OJK).

Munculnya istilah BMT pada awalnya merupakan suatu produk unit usaha yang keberadaannya di bawah Yayasan Inkubasi Bisnis Usaha Kecil (YINBUK). Melalui kerjasama dengan Bank Indonesia dalam proyek Pengembangan Hubungan Bank dengan KSM (PHBK), YINBUK berusaha mengembangkan kerjasama teknis pengembangan BMT dalam bentuk: pertama, melakukan survey indetifikasi terhadap BMT; kedua, memberikan pelatihan-pelatihan kepada BMT dalam meningkatkan kemampuannya mengelola keuangan; ketiga, menyelenggarakan pelatihan bagi pelatih dan pendamping BMT, baik dari bank maupun Lembaga Pengembangan Swadaya Masyarakat (LPSM); keempat, menyelenggarakan pelatihan bagi

Thalis

Noor C

168

JURNAL EKONOMI SYARIAH INDONESIA, Volume II, No.2 Desember 2012 
fasilitator hubungan keuangan bank, khususnya bank syariah; kelima, memberikan kompensasi bagi kegiatan pembinaan BMT yang dilaksanakan oleh LPSM; keenam, menyelenggarakan kegiatan studi banding bagi LPSM dan Bank; ketujuh, memberikan konsultasi kepada Bank (LPSM dan BMT) untuk pengembangan usahanya dan kedelapan, memberikan kegiatan-kegiatan lokakarya, seminar dan sebagainya, yang terkait dengan usaha pengembangan BMT.

Mencermati kelahiran BMT di atas dapat ditarik kesimpulan bahwa sesungguhnya kelahiran BMT didesain bukan untuk menjadi lembaga keuangan formil yang pendiriannya dilandasi oleh dasar hukum yang jelas. Keberadaan BMT sebagai produk YINBUK hanya mendasarkan pada legalitas PINBUK yang berbentuk yayasan serta naskah kerjasama antara Bank Indonesia dengan Yayasan PINBUK Nomor. 003/MoU/PHBK/VIII/95 tertanggal 27 September 1995. Berlandasakan naskah kerjasama inilah kemudian PINBUK mendirikan puluhan BMT di seluruh Indonesia dengan mengeluarkan ijin operasional di bawah Yayasan PINBUK. Ijin operasionalisasi BMT akan diberikan kepada BMT yang berbentuk KSM.

Pada praktiknya KSM tersebut lebih dekat dengan apa yang disebut sebagai lembaga keuangan syariah. Hal ini terlihat dengan adanya Surat Menteri Dalam Negeri Cq Direktorat Jenderal Pembangunan Daerah (BANGDA) tanggal 14 April 1997 Nomor 538/PKK/IV/1997 tentang Status Badan Hukum Lembaga Keuangan Syariah.

Namun demikian, keberadaan BMT saat ini memang belum memiliki payung hukum yang jelas, sehingga membuka peluang terjadinya penyalahgunaan dan penyimpangan. Menurutnya, BMT dalam struktur keuangan mikro di Indonesia memiliki 2 (dua) jenis, pertama merupakan lembaga keuangan mikro non bank formal dan, kedua, lembaga keuangan mikro non bank formal. BMT yang merupakan non bank formal adalah BMT yang telah berbentuk koperasi atau KJKS (Koperasi Jasa Keuangan Syariah). Sedangkan BMT yang berbentuk non bank non formal adalah BMT yang tidak berbentuk koperasi.

Berdasarkan pengamatan Mudrajad, BMT yang berbadan hukum koperasi telah mampu mengatasi kendala-kendala yang dimiliki oleh lembaga keuangan formal seperti bank. BMT ini jugalah yang telah menyelamatkan banyak usaha mikro dan kecil dari cengkraman lintah darat, namun demikian harus diakui bahwa BMT tidak masuk dalam struktur industri perbankan Indonesia.

Ketidakjelasan badan hukum BMT memang menjadi permasalahan tersendiri dalam masyarakat baik dilihat dari aspek tata lembaga keuangannya, maupun dari aspek pertanggungjawaban hukumnya (legal liabilities) baik perdata maupun pidana. Namun demikian merujuk Surat Keputusan Bersama (SKB) antara Menteri Keuangan, Menteri Dalam Negeri, Meneg Koperasi dan UKM bersama Gubernur Bank Indonesia Nomor. 351.1/KMK/010/2009, Nomor: 900-639a tahun 2009, Nomor: 01/SKB/M.KUKM/IX/2009 dan Nomor: 11/43a/KEP.GBI/2009 tentang 169 Strategi Pengembangan Lembaga Keuangan Mikro dapat memilih menjadi 
Bank Perkreditan Rakyat (BPR) atau Koperasi atau Badan Usaha Milik Desa (BUMDes) atau lembaga keuangan lainnya dan sesuai dengan peraturan perundang-undangan yang berlaku. Pada ketentuan ini disepakati untuk melakukan:

a. Bank Indonesia memberikan konsultasi kepada LKM yang akan menjadi BPR/S sesuai dengan ketentuan yang berlaku dalam pendirian dan perizinan $\mathrm{BPR} / \mathrm{S}$;

b. Departemen Dalam Negeri, bersama-sama dengan pemerintah daerah melakukan pembinaan terhadap LKM yang akan menjadi BUMDes;

c. Kementrian Koperasi dan UKM bersama-sama dengan pemerintah daerah memfasilitasi, memberdayakan dan membina LKM yang akan menjadi koperasi;

d. Departemen Keuangan memberikan konsultasi kepada LKM yang kegiatan usahanya menyerupai lembaga keuangan yang berada di dalam pembinaan dan pengawasan Departemen Keuangan menjadi lembaga keuangan sesuai dengan ketentuan yang berlaku.

Berdasarkan SKB tersebut, BMT dapat menentukan pilihan, apakah ia akan menjadi BPR/S, BUMDes atau Koperasi. Pada faktanya memang kemudian banyak BMT memilih menjadi badan hukum Koperasi. Pilihan menjadi badan hukum koperasi ini bermakna bahwa BMT harus tunduk pada ketentuan Undang-undang Nomor 25 Tahun 1992 tentang Perkoperasian, serta peraturan-peraturan lain terkait dengan perkoperasian seperti Peraturan Pemerintah, Peraturan Menteri Koperasi dan UKM dan Keputusan Menteri Koperasi dan UKM.

Berikut dasar hukum yang bisa dijadikan landasan bagi BMT yang akan menjadi Koperasi:

a. Undang-undang Nomor 25 Tahun 1992 tentang Perkoperasian yang telah diganti dengan Undang-undang Nomor 17 Tahun 2012 tentang Perkoperasian.

b. Peraturan Pemerintah Nomor 4 Tahun 1994 tentang Persyaratan dan Tata Cara Pengesahan Akte Pendirian dan Perubahan Anggaran Dasar Koperasi;

c. Peraturan Pemerintah Nomor 17 Tahun 1994 tentang Pembubaran Koperasi oleh Pemerintah;

d. Peraturan Pemerintah Nomor 9 Tahun 1995 tentang Pelaksanaan Kegiatan Usaha Simpan Pinjam Koperasi;

e. Peraturan Menteri Negera Koperasi dan UKM RI Nomor: 35.2/PER/M.KUKM/X/2007 tentang Pedoman Standar Operasional Manajemen Koperasi Jasa Keuangan Syariah (KJKS) dan Unit Jasa Keuangan Syariah (UJKS);

f. Peraturan Menteri Negera Koperasi dan UKM RI Nomor: 35.3/PER/M.KUKM/X/2007 tentang Pedoman Pelaksanaan Penilaian Kesehatan KJKS/UJKS;

g. Peraturan Menteri Negera Koperasi dan UKM RI Nomor: 39/PER/M.KUKM/XII/2007 tentang Pedoman Pengawasan KJKS/UJKS;

h. Peraturan Menteri Negera Koperasi dan UKM RI Nomor: 19/PER/M.KUKM/XI/2008 tentang Pedoman Pelaksanaan Kegiatan Usaha Simpan Pinjam (USP) oleh Koperasi

Thalis

Noor C

170

JURNAL EKONOMI SYARIAH INDONESIA, Volume II, No.2 Desember 2012 
i. Peraturan Menteri Negera Koperasi dan UKM RI Nomor: 21/PER/M.KUKM/XI/2008 tentang Pedoman Pengawasan KSP/USP Koperasi;

j. Keputusan Menteri Negera Koperasi dan UKM RI Nomor: 104.1/Kep/M.KUKM/X/2002 tentang Petunjuk Pelaksanaan Pembentukan, Pengesahan Akta Pendirian dan Perubahan Anggaran Dasar Koperasi;

k. Keputusan Menteri Negera Koperasi dan UKM RI Nomor: 91/Kep/M.KUKM/IX/2004 tentang Petunjuk Pelaksanaan Kegiatan Usaha Koperasi Jasa Keuangan Syariah (KJKS).

Merujuk landasan hukum di atas apabila berbentuk koperasi, BMT harus menjadi Koperasi Jasa Keuangan Syariah (KJKS). Menurut Keputusan Menteri Negera Koperasi dan UKM RI Nomor: 91/Kep/M.KUKM/IX/2004 yang dimaksud dengan KJKS adalah Koperasi yang kegiatan usahanya bergerak di bidang pembiayaan, investasi, dan simpanan sesuai pola bagi hasil (syariah). Sementara menurut Peraturan Menteri Koperasi dan UKM RI Nomor 35.2/PER/M.KUKM/X/2007, yang dimaksud dengan KJKS adalah kegiatan yang dilakukan untuk menghimpun dana dan menyalurkannya melalui usaha jasa keuangan syariah dari dan untuk anggota koperasi yang bersangkutan, calon anggota koperasi yang bersangkutan, koperasi lain dan atau anggotanya.

\section{Produk Penghimpunan Dana BMT}

Sumber dana yang dapat dihimpun oleh KJKS dan UJKS Koperasi digolongkan menjadi empat golongan yaitu: (1) Modal, terdiri dari : Simpanan Pokok dan Simpanan Wajib (untuk KJKS) dan Modal Disetor/ Modal Tetap (untuk UJKS Koperasi) (2) Dana Investasi Tidak Terikat: Simpanan Berjangka Mudharabah, (3) Dana Investasi Terikat Mudharabah Muqayyadah, serta (4) Dana Titipan: Simpanan/Tabungan Wadiah (Kementerian Negara Koperasi dan UKM, 2007).

Produk penghimpunan dana di KJKS atau UJKS Koperasi dibedakan dalam hal akad transaksi yang digunakan yaitu Mudharabah dan Wadiah.

\section{Mudharabah}

Mudharabah adalah akad kerjasama usaha/perniagaan antara pihak pemilik dana (shahibul maal) debagai pihak yang menyediakan modal dana sebesar $100 \%$ dengan pihak pengelola modal (mudharib), untuk diusahakan dengan porsi keuntungan akan dibagi bersama (nisbah) sesuai dengan kesepakatan dimuka dari kedua belah pihak. Sedangkan kerugian (jika ada) akan ditanggung pemilik modal, kecuali jika diketemukan adanya kelalaian atau kesalahan oleh pihak pengelola dana (mudharib), seperti penyelewengan, kecurangan, dan penyalahgunaan dana.

Akad Mudharabah harus memenuhi rukun dan syaratnya. Rukun Mudharabah, yakni: pertama, Pihak yang berakad, yang terdiri dari pemilik Baitul modal (Shahibul Maal) dan pengelola modal (Mudharib). Kedua, objek yang Maal diakadkan, yang terdiri dari modal, kegiatan usaha/kerja dan keuntungan. Ketiga, Sighat/Akad, yang ditandai dengan adanya serah terima. 
Sementara syarat Mudharabah antara lain: Pertama, pihak yang berakad, yakni bahwa kedua belah pihak harus mempunyai kemampuan dan kemauan untuk bekerjasama mudharabah. Kedua, objek yang diakadkan, harus memenuhi ketentuan yakni: harus dinyatakan dalam jumlah/nominal yang jelas; jenis pekerjaan yang dibiayai, dan jangka waktu kerjasama pengelolaan dananya; serta Nisbah (porsi) pembagian keuntungan telah disepakati bersama, dan ditentukan tata cara pembayarannya. Ketiga, dalam sighat/akad, pihak-pihak yang berakad harus jelas dan disebutkan; materi akad yang berkaitan dengan modal, kegiatan usaha/kerja dan nisbah telah disepakati bersama saat perjanjian (akad); risiko usaha yang timbul dari proses kerjasama ini harus diperjelas pada saat ijab qabul, yakni bila terjadi kerugian usaha maka akan ditanggung oleh pemilik modal dan pengelola tidak mendapatkan keuntungan dari usaha yang telah dilakukan; serta untuk memperkecil risiko terjadinya kerugian usaha, pemilik modal dapat menyertakan persyaratan kepada pengelola dalam menjalankan usahanya dan harus disepakati secara bersama.

Akad kerjasama Mudharabah dibedakan menjadi 2 (dua) jenis akad yakni Mudharabah Muthlaqah dan Mudharabah Muqayyadah. Mudharabah Muthlaqah adalah perjanjian mudharabah yang tidak mensyaratkan perjanjian tertentu (investasi tidak terikat), misalnya dalam ijab si pemilik modal tidak mensyaratkan kegiatan usaha apa yang harus dilakukan dan ketentuan-ketentuan lainnya, yang pada intinya memberikan kebebasan kepada pengelola dana untuk melakukan pengelolaan investasinya. Sementara Mudharabah Muqayyadah, adalah akad yang mencantumkan persyaratan-persyaratan tertentu yang harus dipenuhi dan dijalankan oleh si pengelola dana yang berkaitan dengan tempat usaha, tata cara usaha, dan obyek investasinya (investasi yang terikat). Misalnya pengelola dana dipersyaratkan dalam kerjasama untuk tidak mencampurkan dana mudharabah yang diterima dengan dana lainnya; tidak melakukan investasi pada kegiatan usaha yang bersifat sistem jual beli cicilan, tanpa adanya penjamin dan atau tanpa jaminan; atau si pengelola dana harus melakukan sendiri kegiatan usahanya dan tidak diwakilkan kepada pihak ketiga (Djuwaini, 2008).

\section{Wadi'ah}

Wadiah dapat diartikan sebagai titipan murni dari satu pihak ke pihak lain, baik individu maupun badan hukum yang harus dijaga dan dikembalikan kapan saja si pemilik menghendaki. Rukun Wadiah terdiri dari: Pertama, pihak yang berakad yakni orang yang menitipkan (muwaddi) dan orang yang dititipi barang (wadii). Kedua, objek yang diakadkan yakni barang yang dititipkan (wadiah), dan Ketiga, Sighat, yakni adanya serah (ijab) dan terima (qabul).

Sementara syarat Wadiah antara lain: Pertama, pihak yang berakad haruslah cakap hukum, sukarela (ridha) tidak dalam keadaaan dipaksa/terpaksa di bawah tekanan. Kedua, objek yang dititipkan merupakan milik mutlak si pemilik (muwaddi), dan Ketiga, Sighot harus jelas apa yang dititipkan dan tidak mengandung persyaratan-persyaratan lain).

Pada Wadiah terdiri dari 2 (dua) macam akad yakni wadi'ah yad amanah dan wadi'ah yad dhamanah. Akad wadiah yad amanah mensyaratkan

Thalis

Noor C

JURNAL EKONOMI SYARIAH INDONESIA, Volume II, No.2 Desember 2012 
bahwa pihak yang dititipi tidak diperbolehkan memanfaatkan barang yang dititipkan. Pada saat titipan dikembalikan, barang yang dititipkan berada dalam kondisi yang sama pada saat dititipkan. Jika barang yang dititipkan mengalami kerusakan selama masa penitipan maka pihak yang menerima titipan tidak dibebani tanggungjawab. Sebagai imbalan atas tanggungjawab pemeliharaaan titipan, pihak yang menerima titipan dapat meminta biaya penitipan. Sementara pada akad wadiah yad dhamanah, penerima titipan diperbolehkan memanfaatkan dan berhak mendapat keuntungan dari titipan. Penerima titipan bertanggungjawab atas titipan, bila terjadi kerusakan atau kehilangan. Keuntungan yang diperoleh pihak yang menerima titipan dapat diberikan sebagian kepada yang menitipkan sebagai bonus dengan syarat tidak diperjanjikan sebelumnya (Mahkamah Agung, 2008).

\section{Pengawasan BMT berbadan hukum Koperasi}

Pada Baitul Maal wat Tamwil (BMT) berbentuk koperasi yang operasionalisasinya menggunakan prinsip syariah, pengawasannya dilakukan dengan dua model yakni pengawasan internal dan pengawasan eksternal. Pengawasan internal dilakukan oleh dua lembaga pengawas yakni dewan pengawas dan Dewan Pengawas Syariah (DPS). Sementara pengawasan eksternal dilakukan oleh instansi pemerintahan terkait.

\section{Pengawasan Internal dan Pengawasan Syariah}

Pengawas internal dalam kontek perkoperasian disebut dengan Pengawas yang terdiri dari satu orang ketua dan minimal dua orang anggota. Pengawas internal berfungsi untuk mengawasi dari aspek tata kelola BMT berdasarkan prosedur operasional standar (standart operationing procedure) yang ada. Pengawas internal ini dilaksanakan oleh Pengurus atau pihak lain yang ditunjuk oleh Pengurus untuk melaksanakan tugas pengawasan. Pengawasan internal merupakan alat pengendalian manajemen yang mengukur, menganalisis dan menilai efektivitas pengendalian-pengendalian lainnya. Adapun unsur-unsur pengendalian lainnya adalah organisasi, kebijaksanaan, prosedur, personalia, perencanaan akuntansi dan pelaporan (Kementerian Negara Koperasi dan UKM, 2007).

Pada umumnya pengawasan internal bertujuan untuk: pertama, melindungi kekayaan perusahaan; Kedua, memeriksa kecermatan dan keandalan data akutansi; Ketiga, meningkatkan efisiensi operasi usaha; Keempat, mendorong kearah ditaatinya kebijakan yang telah ditetapkan.

Pada dasarnya pengawasan internal bertujuan untuk membantu setiap anggota organisasi melaksanakan tanggung jawabnya secara efektif dan efisien dengan cara menyediakan analisis-analisis, penilaian, rekomendasi-rekomendasi dan komentar mengenai efektivitas yang diperiksa.

Sementara ruang lingkup pengawasan internal meliputi:

Baitul

Maal

1) Penilaian mengenai kelayakan dan kecukupan pengendalian dibidang keuangan, bidang pembiayaan, dan kegiatan koperasi lainnya serta peningkatan efektivitas pengendalian dengan biaya yang layak. 
2) Pemeriksaan untuk memastikan bahwa semua kebijakan, rencana dan prosedur koperasi telah benar-benar ditaati.

3) Pemeriksaan untuk memastikan bahwa semua harta milik koperasi telah dipertanggungjawabkan dan dijaga dari semua kerugian.

4) Pemeriksaan untuk memastikan bahwa data informasi yang disajikan kepada manajemen koperasi dapat dipercaya.

5) Penilaian mengenai kualitas pelaksanaan tugas tiap unit kerja dalam melaksanakan tanggungjawabnya.

6) Memberikan rekomendasi mengenai perbaikan-perbaikan di bidang operasi, pembiayaan dan bidang lainnya.

Menurut Undang-undang Perkoperasian yang lama yakni Undangundang Nomor 25 Tahun 1992 Pasal 39 disebutkan bahwa Pengawas bertugas melakukan pengawasan terhadap pelaksanaan kebijaksanaan dan pengelolaan Koperasi, serta membuat laporan tertulis tentang hasil pengawasannya. Selain itu Pengawas berwenang meneliti catatan yang ada pada koperasi serta mendapatkan segala keterangan yang diperlukan. Setelah Undang-undang Nomor 25 Tahun 1992 diganti dengan Undangundang Nomor 17 Tahun 2012 tentang Perkoperasian, fungsi Pengawas koperasi menjadi lebih luas dibandingkan sebelumnya.

Berdasarkan ketentuan baru tersebut Pengawas bertugas: pertama, mengusulkan calon Pengurus; Kedua, memberi nasihat dan pengawasan kepada Pengurus; Ketiga, melakukan pengawasan terhadap pelaksanaan kebijakan dan pengelolaan Koperasi yang dilakukan oleh Pengurus; dan Keempat, melaporkan hasil pengawasan kepada Rapat Anggota (Undangundang No.17 tahun 2012 tentang Perkoperasian).

Selain itu Pengawas berwenang: pertama, menetapkan penerimaan dan penolakan Anggota baru serta pemberhentian Anggota sesuai dengan ketentuan dalam Anggaran Dasar; Kedua, meminta dan mendapatkan segala keterangan yang diperlukan dari Pengurus dan pihak lain yang terkait; Ketiga, mendapatkan laporan berkala tentang perkembangan usaha dan kinerja Koperasi dari Pengurus; Keempat, memberikan persetujuan atau bantuan kepada Pengurus dalam melakukan perbuatan hukum tertentu yang ditetapkan dalam Anggaran Dasar; dan kelima, dapat memberhentikan Pengurus untuk sementara waktu dengan menyebutkan alasannya.

Sementara pengawasan syariah, meliputi pemantauan (isyraf), pemeriksaan (muraja'ah) dan investigasi (fahsh) yang dimaksudkan untuk menjaga kemaslahatan (mura'at maslahah) dan menghindari kerusakan (idra' mafsadah). Menurut Ridwan, pengawasan syariah yang dilakukan oleh pihak yang berwenang (wilayatul riqabah) bertujuan untuk mengetahui sejauh mana proses kegiatan usaha pada satuan kerja organisasi dan mendapatkan konfirmasi bahwa seluruh aktifitas keuangan dan penerapan strategi serta tujuan organisasi tidak bertentangan dengan prinsip-prinsip syariah.

Pengawasan syariah tersebut dilakukan oleh Dewan Pengawas Syariah (DPS) yang merupakan dewan yang dipilih oleh koperasi yang bersangkutan berdasarkan keputusan rapat anggota dan beranggotakan alim ulama yang ahli dalam syariah yang menjalankan fungsi dan tugas sebagai pengawas syariah pada koperasi yang bersangkutan dan

Thalis

Noor C

174

JURNAL EKONOMI SYARIAH INDONESIA, Volume II, No.2 Desember 2012 
berwenang memberikan tanggapan atau penafsiran terhadap fatwa yang dikeluarkan Dewan Syariah Nasional (Kementerian Negara Koperasi dan UKM, 2007).

Dewan Syariah Nasional (DSN) merupakan Dewan Syariah yang dibentuk oleh Majelis Ulama Indonesia (MUI) pada tahun 1998 dan dikukuhkan oleh Surat Keputusan (SK) Pimpinan MUI No.Kep754/MUI/II/1999 tanggal 10 Februari 1999 (Nadratuzzaman, Hilda, dan Yoga, 2008).

Keberadaan DSN memiliki tugas yang sangat penting dalam mengawasl perjalanan lembaga bisnis syariah. Tugas DSN meliputi:

1) Menumbuh kembangkan penerapan nilai-nilai syariah dalam kegiatan perekonomian pada umumnya dan sector keuangan pada khususnya, termasuk usaha bank, asuransi dan reksadana

2) Mengeluarkan fatwa atas produk dan jasa keuangan syariah. Selain itu DSN juga memiliki wewenang antara lain:

1) Mengeluarkan fatwa yang mengikat DPS (Dewan Pengawas Syariah) pada masing-masing lembaga keuangan syariah dan menjadi dasar tindakan hukum bagi pihak terkait;

2) Mengeluarkan fatwa yang harus menjadi landasan bagi ketentuan yang dikeluarkan oleh institusi-institusi yang berwenang terkait seperti BI, Bappepam dan Kementerian Keuangan;

3) Memberikan rekomendasi atau mencabut rekomendasi nama-nama yang akan duduk sebagai anggota DPS pada suatu lembaga keuangan syariah;

4) Mengundang para ahli untuk memberikan penjelasan terhadap suatu masalah yang diperlukan dalam pembahasan ekonomi syariah termasuk otoritas atau lembaga baik dalam maupun luar negeri;

5) Mengusulkan kepada pihak yang berwenang untuk mengambil tindakan hukum apabila peringatan tidak diindahkan;

6) Memberikan peringatan kepada lembaga keuangan syariah untuk menghentikan penyimpangan dari fatwa yang telah dikeluarkan oleh DSN.

Keberadaan DPS didasarkan pada Surat Keputusan DSN No.3 tahun 2003, di mana dijelaskan bahwa DPS adalah bagian dari Lembaga Keuangan Syariah (LKS) yang bersangkutan, di mana penempatannya atas persetujuan DSN. DPS memiliki fungsi antara lain:

1) Melakukan pengawasan secara periodik pada LKS yang berada di bawah pengawasannya;

2) Berkewajiban mengajukan usul-usul pengembangan LKS kepada pimpinan lembaga yang bersangkutan dan kepada DSN;

3) Melaporkan perkembangan produk dan operasional LKS yang diawasinya kepada DSN minimal dua kali dalam satu tahun anggaran;

Baitul

4) Merumuskan permasalahan-permasalahan yang memerlukan pembahasan DSN.

Selain tugas dan fungsi yang terdapat pada DPS di atas, pengawasan yang dilakukan oleh DPS wajib mengacu pada prinsip-prinsip 175 dasar pengawasan dalam Islam, yang meliputi:

JURNAL EKONOMI SYARIAH INDONESIA, Volume II, No.2 Desember 2012 
1) Jalbul mashalih, yaitu menerapkan, mengambil dan menjaga unsurunsur kebaikan (maslahah) serta memaksimalkan kebaikan tersebut (ta'dzim mashalih). Jalbul mashalih dilaksanakan dalam rangka menjaga dan memelihara maqashid syariah (terpeliharanya lima maslahah) yakni risiko moral dan agama (hifdz din), risiko akal/intelektual (hifdz 'aql), resiko keuangan (hifdz maal), risiko generasi dan reproduksi (hifdz nasl) serta risiko reputasi (hifdz irdh).

2) Dar'ul mafasid, yaitu menghindarkan dari unsur-unsur yang dapat menimbulkan kerusakan dan keburukan (mafsadah) serta dapat meminimalisir risiko. Prinsip ini dilakukan dalam rangka menghindarkan praktik atau kegiatan yang dapat menyebabkan timbulnya kerusakan maqashid syariah serta kerugian material lainnya.

3) Saddudz dzari'ah yaitu prinsip kehati-hatian untuk mencegah dan mengantisipasi adanya resiko pelanggaran terhadap syariah dan peraturan-peraturan lainnya yang berlaku. Prinsip ini mengandung makna bahwa setiap individu, satuan organisasi maupun pihak otoritas dapat melakukan tindakan pencegahan dan sikap kehatihatian (ihtiyath) untuk mengantisipasi kemungkinan terjadinya praktik pelanggaran terhadap ketentuan syariah atau ketentuan lainnya dengan tetap mempertimbangkan aspek pertumbuhan, produktifitas, profitabilitas, kemanfaatan dan kemaslahatan.

\section{Pengawasan Ekternal}

BMT yang berbadan hukum Koperasi Jasa Keuangan Syariah (KJKS) sepenuhnya sistem pengawasan eksternalnya tunduk pada Peraturan Menteri Negara (Permeneg) Koperasi dan UKM RI Nomor.39/Per/M.KUKM/XII/2007 tentang Pedoman Pengawasan Koperasi Jasa Keuangan Syariah dan Unit Jasa Keuangan Syariah.

Berdasarkan Pasal 1 angka (1) Peraturan Menteri tersebut, yang dimaksud dengan pengawasan adalah kegiatan pembinaan, pemantauan, pemeriksaan, dan penilaian kesehatan Koperasi Jasa Keuangan Syariah dan Unit Jasa Keuangan Syariah Koperasi oleh pemerintah dalam hal ini Menteri di tingkat pusat dan pejabat yang diberi wewenang menjalankan tugas pembantuan di tingkat daerah dengan tujuan agar pengelolaan Koperasi Jasa Keuangan Syariah dan Unit Jasa Keuangan Syariah Koperasi dilakukan secara baik dan terkendali sehingga menumbuhkan kepercayaan dari pihak terkait.

Sementara tujuan pengawasan KJKS/UJKS berdasarkan Pasal 2 adalah:

1) mengendalikan KJKS dan UJKS Koperasi agar dalam menjalankan kegiatan operasinya sesuai dengan ketentuan hukum yang berlaku;

2) meningkatkan citra dan kredibilitas KJKS dan UJKS Koperasi sebagai lembaga keuangan yang mampu mengelola dana dari anggota, calon anggota, koperasi lain dan atau anggotanya berdasarkan prinsip koperasi;

3) menjaga dan melindungi asset KJKS dan UJKS Koperasi dari tindakan penyelewengan oleh pihak-pihak yang tidak bertanggung jawab;

4) meningkatkan transparansi dan akuntabilitas pengelolaan KJKS dan UJKS Koperasi terhadap pihak-pihak yang berkepentingan;

Thalis

Noor C

176

JURNAL EKONOMI SYARIAH INDONESIA, Volume II, No.2 Desember 2012 
5) mendorong pengelolaan KJKS dan UJKS Koperasi mencapai tujuannya secara efektif dan efisien yaitu meningkatkan pemberdayaan ekonomi anggota.

Selain tujuan tersebut pengawasan KJKS/UJKS juga memiliki ruang lingkup antara lain:

1) Pembinaan pelaksanaan pengendalian internal KJKS dan UJKS Koperasi sesuai dengan ketentuan yang berlaku;

2) Pemantauan perkembangan KJKS dan UJKS Koperasi secara berkala melalui laporan keuangan KJKS dan UJKS Koperasi yang bersangkutan;

3) Pemeriksaan terhadap KJKS dan UJKS Koperasi yang menyangkut organisasi dan usahanya, termasuk program pembinaan anggota sesuai Standar Operasional Manajemen (SOM) dan Standar Operasional Prosedur (SOP) KJKS dan UJKS Koperasi;

4) Penilaian kesehatan KJKS dan UJKS Koperasi sesuai standar kesehatan KJKS dan UJKS Koperasi yang diatur dalam ketentuan yang berlaku (Peraturan Menteri Negara Koperasi dan UKM RI, 2007).

Pada proses pengawasan KJKS/UJKS, pemerintah melalui Kementerian Koperasi dan UKM mengangkat Pejabat Pengawas yang berperan sebagai pengawas Koperasi Jasa Keuangan Syariah dan Unit Jasa Keuangan Syariah Koperasi. Pejabat pengawas mempunyai wewenang:

1) menerima laporan mengenai kondisi organisasi, usaha dan permodalan Koperasi Jasa Keuangan Syariah dan atau Unit Jasa Keuangan Syariah;

2) melakukan audit atau meminta auditor independen untuk melakukan audit terhadap semua dana, surat-surat berharga, pembukuan, kertas kerja, catatan dan semua sumber informasi yang dikuasainya serta laporan pemeriksaan oleh pengawas yang akan diberikan kepada pengurus Koperasi Jasa Keuangan Syariah dan atau Unit Jasa Keuangan Syariah Koperasi;

3) merekomendasikan kepada Menteri untuk menghentikan kegiatan usaha dan atau mencabut izin usaha Jasa Keuangan Syariah apabila terdapat dugaan kuat berdasarkan bukti-bukti nyata yang ditemukan bahwa Koperasi Jasa Keuangan Syariah dan atau Unit Jasa Keuangan Syariah: a) menjalankan usaha keuangan yang tidak sehat dan tidak aman; b) melanggar ketentuan hukum dan peraturan perundangundangan yang berlaku; atau;

4) mengeluarkan perintah untuk menempatkan Koperasi Jasa Keuangan Syariah dan atau Unit Jasa Keuangan Syariah dalam pengawasan administratif.

\section{Perlindungan Hukum atas Dana yang disimpan di BMT}

Perlindungan hukum terbagi menjadi dua bentuk yakni perlindungan hukum preventif dan perlindungan hukum represif, demikian pulan dalam konteks Baitul Maal wat Tamwil (BMT). Maal Perlindungan hukum preventif pada BMT terwujud dengan tersedianya landasan hukum bagi berdiri dan operasionalisasinya sebuah BMT, baik 
berupa keabsahan badan hukumnya, profesionalitas tata kelolanya yang sesuai dengan SOP dan SOM nya atau tidak.

BMT dengan bentuk yang bervariasi, LKMS dan Koperasi/KJKS atau UJKS, melahirkan konsekuensi proteksi hukum yang berbeda pula. Secara preventif BMT yang hanya berbentuk LKMS tidak memiliki proteksi hukum yang kuat yang dapat memberikan jaminan hukum atas dana yang disimpan oleh masyarakat di LKMS tersebut. Sebagaimana telah diuraikan di atas, eksistensi BMT yang berbentuk LKMS tidak terwadahi dalam payung hukum yang jelas, sehingga dengan demikian segala operasionalisasi dan manajemen keuangannya juga tidak memiliki landasan hukum yang bisa dipertanggungjawabkan, yang pada akhirnya menyebabkan tidak terjaminnya dana masyarakat yang disimpan.

Berbeda dengan BMT yang hanya berbentuk LKMS, BMT yang berbadan hukum koperasi baik yang berbentuk KJKS maupun UJKS relatif lebih terproteksi secara hukum. Melihat dari aspek prevensinya, KJKS/UJKS memiliki landasan hukum yang lebih kuat karena didasarkan pada Keputusan dan Peraturan Menteri Negara Koperasi dan UKM yakni Keputusan Menteri Negera Koperasi dan UKM RI Nomor: 91/Kep/M.KUKM/IX/ 2004 tentang Petunjuk Pelaksanaan Kegiatan Usaha Koperasi Jasa Keuangan Syariah (KJKS) dan Peraturan Menteri Negera Koperasi dan UKM RI Nomor: 35.2/PER/M.KUKM/X/2007 tentang Pedoman Standar Operasional Manajemen Koperasi Jasa Keuangan Syariah (KJKS) dan Unit Jasa Keuangan Syariah (UJKS). Kedua aturan tersebut bersandar pada Undang-undang Perkoperasian, sehingga memiliki proteksi preventif yang kuat, terlebih dalam Undang-undang Koperasi yang baru saja disahkan telah menetapkan adanya sistem perlindungan simpanan dengan membuat Lembaga Penjamin Koperasi Simpan Pinjam (LP-KSP) yang tentunya lebih memberikan jaminan perlindungan kepada masyarakat yang menyimpan dananya di koperasi.

Namun demikian, baik BMT yang berbentuk LKMS maupun BMT yang berbadan hukum koperasi (KJKS/UJKS) memiliki peluang perlindungan hukum yang sama secara represif. Sebagaimana telah dijelaskan di atas, bahwa perlindungan hukum represif lebih mengedepankan pada penyelesaian pertanggungjawaban melalui jalurjalur hukum baik non-litigasi maupun litigasi.

Jalur non-litigasi berupa jalur-jalur musyawarah baik langsung maupun melalui perantara, seperti mediasi (Sutiyoso, 2006), negoisasi, konsiliasi, maupun arbitrase dan sengketa konsumen. Penyelesaian melalui mediasi, negoisasi, konsiliasi serta arbitrase disandarkan pada aturan main yang telah tercantum pada Undang-undang Nomor 30 tahun 1999 tentang Arbitrase dan Alternatif Penyelesaian Sengketa (APS). Sementara penyelesaian sengketa konsumen dapat diajukan di Badan Penyelesaian Sengketa Konsumen (BPSK) berdasarkan ketentuan Undangundang Nomor 8 Tahun 1999 tentang Perlindungan Konsumen (UUPK).

Jalur litigasi merupakan penyelesaian melalui pengadilan yang berwenang yakni melalui gugatan di Pengadilan Agama atau permohonan pailit di Pengadilan Niaga pada Pengadilan Negeri.

Menurut Pasal 49 huruf (i) Undang-undang Nomor 3 Tahun 2006 tentang Perubahan atas Undang-undang Nomor 7 Tahun 1989 tentang

Thalis

Noor C

178

JURNAL EKONOMI SYARIAH INDONESIA, Volume II, No.2 Desember 2012 
Peradilan Agama, Lembaran Negara RI Tahun 2006 Nomor 22, menyebutkan bahwa Pengadilan Agama bertugas dan berwenang memeriksa, memutus dan menyelesaikan perkara di tingkat pertama antara orang-orang yang beragama Islam di bidang ekonomi syariah.

Penjelasan mengenai Pasal 49 huruf (i) tersebut menerangkan bahwa yang dimaksud dengan "ekonomi syariah" adalah perbuatan atau kegiatan usaha yang dilaksanakan menurut prinsip syariah, antara lain meliputi: a. bank syariah; b. lembaga keuangan mikro syariah. c. asuransi syariah; d. reasuransi syariah; e. reksa dana syariah; f. obligasi syariah dan surat berharga berjangka menengah syariah; g. sekuritas syariah; $h$. pembiayaan syariah; i. pegadaian syariah; j. dana pensiun lembaga keuangan syariah; dan k. bisnis syariah.

BMT baik yang berbentuk LKMS maupun KJKS/UJKS merupakan bagian dari lembaga keuangan mikro syariah sebagaimana huruf (b) serta termasuk menjadi bagian dari bisnis syariah sebagaimana huruf $(\mathrm{k})$ yang terangkum dalam kegiatan ekonomi syariah sebagaimana penjelasan Pasal 49 Undang-undang Nomor 3 Tahun 2006.

Selain gugatan ke Pengadilan Agama, penyelesaian melalui jalur litigasi dapat pula dilakukan dengan pengajuan permohonan pailit ke Pengadilan Niaga pada Pengadilan Negeri setempat. Pengajuan kepailitan ini didasarkan pada Undang-undang Nomor 37 Tahun 2004 tentang Kepailitan dan Penundaan Kewajiban Pembayaran Utang (PKPU) Lembaran Negara RI Tahun 2004 Nomor 131. Kepailitan adalah sita umum atas semua kekayaan Debitor Pailit yang pengurusan dan pemberesannya dilakukan oleh Kurator di bawah pengawasan Hakim Pengawas (Undangundang Nomor 37 Tahun 2004). Pengajuan pailit hanya dapat dilakukan manakala Debitor yang mempunyai dua atau lebih Kreditor dan tidak membayar lunas sedikitnya satu utang yang telah jatuh waktu dan dapat ditagih, dinyatakan pailit dengan putusan Pengadilan, baik atas permohonannya sendiri maupun atas permohonan satu atau lebih kreditornya.

\section{PROBLEM DAN TANTANGAN YANG TERSERAK Legalitas dan Peran Dewan Pengawas Syariah}

Keberadaan DPS tidak diatur dalam Undang-undang Koperasi baik yang lama maupun yang baru. Keberadaannya hanya dinyatakan dalam Keputusan Menteri Negara Koperasi dan UKM Nomor: 91/Kep/M.KUKM/IX/2004 tentang Petunjuk Pelaksanaan Usaha KJKS dan juga Peraturan Menteri Negara Koperasi dan UKM Nomor: 35.2/Per/M.KUKM/X/2007 tentang Pedoman SOM KJKS dan UJKS. Akan tetapi aturan di atas nampak masih tidak konsisten mengatur tentang posisi DPS. Keputusan Menteri di atas, menyiratkan bahwa posisi DPS hanya bersifat fakultatif bukan wajib dalam pendirian sebuah koperasi syariah (KJKS). Hal ini ditunjukkan pertentangan pada Pasal 4 huruf (d)

Baitul angka (2) yang menyebutkan bahwa diperlukan Fatwa Dewan Syariah Maal sedangkan pada butir (6), pembentukan Dewan Syariah hanya diperuntukkan bagi KJKS/UJKS yang telah mampu mengangkatnya. 
Inkonsistensi dalam Kepmeneg KUKM di atas, tidak hanya terjadi pada wajib tidaknya DPS, akan tetapi juga kerancuan penyebutan antara Dewan Pengawas Syariah dan Dewan Syariah, demikian pula tentang tidak adanya ketentuan mengenai persyaratan bagaimana dan siapa yang dapat merekomendasikan seorang ulama yang ahli ekonomi syariah sebagaimana pengertian DPS yang telah dikemukakan yakni dewan yang dipilih oleh koperasi yang bersangkutan berdasarkan keputusan rapat anggota dan beranggotakan alim ulama yang ahli dalam ekonomi syariah yang menjalankan fungsi dan tugas sebagai pengawas syariah pada koperasi. Pengertian tersebut tidak diikuti dengan penjelasan mengenai apakah seorang yang ahli ekonomi syariah yang bukan ulama berarti tidak diperbolehkan menjadi anggota DPS.

Ketidakjelasan posisi DPS ini pada praktiknya juga tidak menjadi persoalan dalam hal pengesahan pendirian sebuah koperasi syariah (KJKS), KSUS BMT ISRA menjadi contoh nyata disahkannya status badan hukum tahun 2008 di mana dalam strukturnya tidak ditemukan adanya DPS KSUS BMT ISRA. Peraturan Pemerintah Nomor 4 Tahun 1994 tentang Persyaratan dan Tata Cara Pengesahan Akta Pendirian dan Perubahan Anggaran Dasar Koperasi, sendiri tidak pernah mensyaratkan adanya DPS, karena memang lahirnya KJKS jauh setelah PP ini disahkan yakni sekira 10 tahun setelahnya.

Namun demikian, sudah seharusnya ada penyelarasan atau harmonisasi antara satu produk hukum dengan produk hukum lainnya terlebih antara peraturan lama dengan peraturan yang baru, sehingga tidak terkesan tumpah tindak ataupun saling bertentangan. Secara hirarkhi yuridis, posisi Peraturan Pemerintah (PP) memiliki level yang lebih tinggi dan lebih kuat dibandingkan dengan peraturan di bawahnya semisal Peraturan Menteri (Permen) atau hanya Keputusan Menteri (Kepmen). Permen atau Kepmen tidak bisa mengalahkan kekuatan hukumnya dibandingkan PP. Hal inilah yang menjadi persoalan dalam konteks koperasi syariah, di mana terdapat banyak inovasi aturan main akan tetapi hanya di level bawah yakni berupa Kepmen dan Permen, sementara aturan di atasnya belum pernah berubah, dan menariknya inovasi yang terjadi terkesan menegasikan peraturan yang lebih tinggi. Sebuah harapan terhadap pengesahan Undang-undang perkoperasian yang baru dapat melahirkan peraturan-peraturan pelaksanaan di bawahnya dengan harmonis dan tidak saling tumpang-tindih.

DPS sebagai pengawas syariah dalam konteks legal, memerlukan payung hukum yang kuat, sehingga dapat berperan maksimal terutama dalam aspek pengawasan terhadap pembuatan produk KJKS dan aplikasinya di masyarakat. Selain itu pengawasan terhadap DPS juga diperlukan, karena pada faktanya terdapat DPS lepas tanpa pengawasan, bahkan cenderung hanya 'numpang nama' tanpa melakukan apapun namun tetap menerima gaji bulanan.

\section{Lemahnya Kontrol Pemerintah}

Faktor lain yang sesungguhnya krusial adalah lemahnya kontrol yuridis dari otoritas pengawasan pemerintah yakni Kementerian Koperasi maupun Dinas Koperasi, padahal fungsi pengawasan melekat pada pemerintah.

Thalis

Noor C

180

JURNAL EKONOMI SYARIAH INDONESIA, Volume II, No.2 Desember 2012 
Pengawasan oleh pemerintah tersebut adalah pengawasan dalam arti kegiatan pembinaan, pemantauan, pemeriksaan, dan penilaian kesehatan KJKS dan UJKS Koperasi oleh pemerintah dalam hal ini Menteri di tingkat pusat dan pejabat yang diberi wewenang menjalankan tugas pembantuan di tingkat daerah dengan tujuan agar pengelolaan KJKS dan UJKS Koperasi dilakukan secara baik dan terkendali sehingga menumbuhkan kepercayaan dari pihak terkait (Peraturan Menteri Negara Koperasi dan UKM RI, 2007).

Undang-undang Nomor 25 Tahun 1992 tidak menerangkan tentang pengawasan terhadap koperasi oleh pemerintah, akan tetapi Undangundang Nomor 17 Tahun 2012 menerangkan cukup detail tentang bagaimana pengawasan oleh pemerintah dilakukan.

Merujuk Pasal 97 Undang-undang tersebut, Pengawasan dilakukan melalui pelaporan, pemantauan, dan evaluasi terhadap Koperasi. Kegiatan pengawasan melalui pelaporan dilakukan dengan cara: pertama, meneliti laporan pertanggungjawaban tahunan, dokumen-dokumen, dan keputusan-keputusan Rapat Anggota; kedua, meminta untuk hadir dalam Rapat Anggota; dan/atau ketiga, memanggil Pengurus untuk diminta keterangan mengenai perkembangan Koperasi.

Sementara kegiatan pengawasan melalui pemantauan dan evaluasi dilakukan dengan mengamati dan memeriksa laporan. Apabila dari hasil pemantauan dan evaluasi terbukti terjadi penyimpangan, Menteri wajib mengambil langkah penyelesaian sesuai dengan ketentuan undangundang.

Selain melakukan pengawasan, pemerintah melalui Menteri juga dapat melakukan pemeriksaan terhadap Koperasi, dalam hal: pertama, Koperasi membatasi keanggotaan atau menolak permohonan untuk menjadi Anggota atas orang perseorangan yang telah memenuhi persyaratan keanggotaan sebagaimana ditetapkan dalam Anggaran Dasar; Kedua, Koperasi tidak melaksanakan Rapat Anggota Tahunan dalam waktu 2 (dua) tahun berturut-turut; Ketiga, kelangsungan usaha Koperasi sudah tidak dapat diharapkan; dan/atau Keempat, terdapat dugaan kuat bahwa Koperasi yang bersangkutan tidak mengelola administrasi keuangan secara benar.

Menteri dalam melakukan pemeriksaan dapat menunjuk Akuntan Publik, yang biayanya dibebankan pada Anggaran Pendapatan dan Belanja Negara sesuai dengan ketentuan peraturan perundangundangan. Setelah itu Menteri menyampaikan salinan laporan pemeriksaan kepada Koperasi yang bersangkutan dan kepada pihak yang berkepentingan.

Sementara menurut Peraturan Menteri Negara Koperasi dan UKM Nomor: 39/Per/M.KUKM/XII/2007 tertanggal 4 Desember 2007 tentang Pedoman Pengawasan KJKS dan UJKS Koperasi disebutkan bahwa tujuan pengawasan KJKS dan UJKS Koperasi adalah: pertama, mengendalikan KJKS dan UJKS Koperasi agar dalam menjalankan kegiatan operasinya Maal sesuai dengan ketentuan hukum yang berlaku; Kedua, meningkatkan citra dan kredibilitas KJKS dan UJKS Koperasi sebagai lembaga keuangan yang 
mampu mengelola dana dari anggota, calon anggota, koperasi lain dan atau anggotanya berdasarkan prinsip koperasi;

Ketiga, menjaga dan melindungi asset KJKS dan UJKS Koperasi dari tindakan penyelewengan oleh pihak-pihak yang tidak bertanggungjawab; Keempat, meningkatkan transparansi dan akuntabilitas pengelolaan KJKS dan UJKS Koperasi terhadap pihak-pihak yang berkepentingan; Kelima, mendorong pengelolaan KJKS dan UJKS Koperasi mencapai tujuannya secara efektif dan efisien yaitu meningkatkan pemberdayaan ekonomi anggota.

Adapun ruang lingkup Pengawasan KJKS dan UJKS Koperasi meliputi: Pertama, pembinaan pelaksanaan pengendalian internal KJKS dan UJKS Koperasi sesuai dengan ketentuan yang berlaku; Kedua, pemantauan perkembangan KJKS dan UJKS Koperasi secara berkala melalui laporan keuangan KJKS dan UJKS Koperasi yang bersangkutan; Ketiga, pemeriksaan terhadap KJKS dan UJKS Koperasi yang menyangkut organisasi dan usahanya, termasuk program pembinaan anggota sesuai Standar Operasional Manajemen (SOM) dan Standar Operasional Prosedur (SOP) KJKS dan UJKS Koperasi; Keempat, penilaian kesehatan KJKS dan UJKS Koperasi sesuai standar kesehatan KJKS dan UJKS Koperasi yang diatur dalam ketentuan yang berlaku.

\section{Dinas Koperasi, antara Kambing Hitam dan Cuekisme}

Ada suatu pendapat yang menganggap bahwa Dinas Koperasi selalu menjadi kambing hitam setiap terjadi kekisruhan dalam koperasi, padahal hal tersebut belum tentu menjadi ranah Dinas Koperasi. Pengawasan terhadap koperasi sangat tergantung pada pejabat mana yang mengesahkan koperasi sebagai badan hukum.

Jika dirunut dari aturan main yang ada, sesungguhnya yang dapat ditarik sebagai pihak yang patut disalahkan adalah pemerintah pusat dalam hal ini adalah Kementrian Koperasi dan UKM yang tidak konsisten dan konsekuen terhadap aturan yang dibuatnya sendiri, termasuk dalam kaitan ini adalah tentang Pengawasan KJKS dan UJKS Koperasi sebagaimana Permeneg KUKM Nomor: 39/Per/M.KUKM/XII/2007.

Pasal 17 Permeneg tersebut menyebutkan bahwa Menteri mengangkat Pejabat Pengawas yang berperan sebagai pengawas KJKS dan UJKS Koperasi yang bertanggung jawab melakukan pengawasan dan mempunyai wewenang: a) menerima laporan mengenai kondisi organisasi, usaha dan permodalan KJKS dan UJKS; b) melakukan audit atau meminta auditor independen untuk melakukan audit terhadap semua dana, suratsurat berharga, pembukuan, kertas kerja, catatan dan semua sumber informasi yang dikuasainya serta laporan pemeriksaan oleh pengawas yang akan diberikan kepada pengurus KJKS dan UJKS; c) merekomendasikan kepada Menteri untuk menghentikan kegiatan usaha dan atau mencabut izin usaha Jasa Keuangan Syariah apabila terdapat dugaan kuat berdasarkan bukti-bukti nyata yang ditemukan bahwa KJKS dan UJKS: menjalankan usaha keuangan yang tidak sehat dan tidak aman; atau melanggar ketentuan hukum dan peraturan perundang-undangan yang berlaku; atau d) mengeluarkan perintah untuk menempatkan KJKS dan UJKS dalam pengawasan administratif.

Thalis

Noor C

182 
Selanjutnya dalam ketentuan peralihan disebutkan bahwa Pengangkatan Pejabat pengawas sebagaimana dimaksud dalam pasal 17 dilaksanakan dalam jangka waktu paling lambat 2 (dua) tahun sejak tanggal berlakunya peraturan ini. Sebelum pejabat pengawas sebagaimana dimaksud dalam Pasal 17 terbentuk, maka penyelenggaraan tugas pengawasan terhadap KJKS dan UJKS Koperasi dilakukan oleh Deputi.

Melihat dari aturan ini, persoalan tentang siapa yang harus bertanggungjawab tentang pengawasan KJKS menjadi semakin jelas, karena hingga kini lebih dari 2 (dua) tahun semenjak Permeneg tersebut ditandatangani Menteri Koperasi belum juga mengangkat apa yang disebut sebagai Pejabat Pengawas, dan oleh karenanya berdasarkan ayat (2) pengawasan masih dipegang oleh Deputi, yang pada kenyataanya pengawasan oleh Deputi nyaris tidak dilakukan.

Hal mendasar dalam persoalan pada produk simpanan di luar perbankan adalah tidak adanya perlindungan hukum yang disebabkan tidak adanya sistem penjaminan atas dana yang disimpan dalam produkproduk simpanan tersebut. Undang-undang Nomor 25 Tahun 1992 tentang Perkoperasian tidak memberikan perlindungan dalam bentuk sistem penjaminan simpanan perkoperasian. Perlindungan yang diberikan hanya pada masalah siapa yang harus bertanggungjawab manakala koperasi terjadi persoalan kebangkrutan atau terjerat masalah hukum.

Pasal 34 Undang-undang Nomor 25 Tahun 1992 menyatakan bahwa Pengurus, baik bersama-sama, maupun sendiri-sendiri, menanggung kerugian yang diderita Koperasi, karena tindakan yang dilakukan dengan kesengajaan atau kelalaiannya. Apabila tindakan itu dilakukan dengan kesengajaan, tidak menutup kemungkinan bagi penuntut umum untuk melakukan penuntutan.

Peraturan Menteri Negara Koperasi dan UKM Nomor: 35.2/Per/M.KUKM/X/2007 tentang Pedoman SOM KJKS dan UJKS juga menyatakan bahwa manakala terjadi kerugian maka akan ditanggung oleh pemilik modal (shahibul maal), kecuali jika diketemukan adanya kelalaian atau kesalahan oleh pihak pengelola dana (mudharib). Kelalaian atau kesalahan oleh pihak pengelola dana tersebut ditunjukkan antara lain: pertama, tidak dipenuhinya persyaratan yang ditentukan di dalam akad; Kedua, tidak terdapat kondisi di luar kemampuan (force majeur) yang lazim dan/atau yang telah ditentukan di dalam akad; atau Ketiga, hasil putusan dari badan arbitrase atau pengadilan.

Kementerian Koperasi dan UKM selaku regulator juga mengakui bahwa tidak adanya kebijakan perlindungan atas simpanan menjadi masalah penting bagi pemerintah. Pengakuan kementerian ini tercermin dari salah satu bagian dari salah satu Bab yang ada dalam Peraturan Menteri Negara Koperasi dan UKM Nomor: 35.2/Per/M.KUKM/X/2007. Pemerintah menyatakan bahwa para penyimpan dan para deposan pada Baitul lembaga keuangan perbankan mendapat perlindungan dari Bank Maal Indonesia yang mendorong masyarakat untuk menabung di bank, sedangkan para penyimpan dan deposan pada KJKS atau UJKS Koperasi 183 belum ada ketentuan yang mengatur tentang itu. Hal ini perlu dijadikan 
tantangan bagi pihak manajemen untuk merumuskan kebijakan perlindungan simpanan seperti melakukan kerjasama dengan KJKS dan UJKS Koperasi sekunder atau asosiasi KJKS dan UJKS Koperasi untuk meluncurkan produk perlindungan simpanan bagi KJKS dan UJKS Koperasi yang tidak bertentangan dengan peraturan yang berlaku (Peraturan Menteri Negara Koperasi dan UKM RI, 2007).

Pernyataan pemerintah tersebut sesungguhnya menunjukkan bahwa pemerintah tidak mampu membuat suatu kebijakan tentang perlindungan hukum atas simpanan yang ada dan dijalankan oleh KJKS/UJKS sebagaimana dalam perbankan. Justru yang terjadi adalah bahwa pemerintah melempar tanggungjawab atas perlindungan simpanan kepada masing-masing KJKS/UJKS, dan menyerahkan sepenuhnya kebijakan tersebut kepada masing-masing KJKS/UJKS dengan catatan hal tersebut tidak bertentangan dengan aturan hukum yang berlaku. Peraturan Menteri tersebut juga mengisyaratkan kegagalan pemerintah dalam menciptakan perlindungan dan kepastian hukum atas dana masyarakat yang disimpan pada produk-produk simpanan KJKS/UJKS, padahal pemerintah selalu mendorong tentang pentingnya koperasi karena merupakan soko guru ekonomi bangsa dan menjadi satu-satunya elemen ekonomi yang paling tangguh menghadapi krisis. Namun, ternyata pemerintah selaku regulator justru gagal menciptakan suatu sistem perlindungan atas simpanan yang dijalankan oleh koperasi.

Akibat tidak adanya sistem perlindungan atas simpanan yang ada di KJKS/UJKS maka tidak heran, manakala KJKS/UJKS mengalami permasalahan hukum, masyarakat penyimpanlah yang selalu menjadi korban. Sementara pemerintah melalui Kementerian Koperasi ataupun Dinas Koperasi terkesan justru lepas tangan, dan melempar kesalahan hanya pada pengurus dan manajemen KJKS/UJKS, tanpa pernah melakukan evaluasi, pengawasan maupun pembinaan sebagaimana telah diamanahkan dalam Undang-Undang Perkoperasian dan Peraturan Menteri Koperasi. 


\section{Daftar Pustaka}

Bambang Sutiyoso, Penyelesaian Sengketa Bisnis, Yogyakarta: Citra Media, 2006.

Dimyauddin Djuwaini, Pengantar Figh Muamalah, Yogyakarta: Pustaka Pelajar, 2008

Kajian Ekonomi dan Keuangan (Edisi Khusus) Jakarta: Pusat Pengkajian Ekonomi dan Keuangan, Badan Pengkajian Ekonomi, Keuangan dan Kerjasama Internasional, Departemen Keuangan, 2005.

Kompilasi Hukum Ekonomi Syariah (KHES), Mahkamah Agung RI, 2008

M. Nadratuzzaman H, Hilda S dan R.Yoga P, Lembaga Bisnis Syariah, Jakarta: PKES Publishing, 2008.

Media Informasi Bank Perkreditan Rakyat, Edisi IV Maret 2005.

Usman S, W.I.Suharyo, et.al, Keuangan Mikro untuk Masyarakat Miskin: Pengalaman Nusa Tenggara Timur, Jakarta: Lemlit SMERU, 2004.

Peraturan Menteri Negara Koperasi dan UKM Nomor: 35.2/Per/M.KUKM/X/2007 tentang Pedoman Standar Operasional Manajemen Koperasi Jasa Keuangan Syariah (KJKS) dan Unit Jasa Keuangan Syariah (UJKS).

Peraturan Menteri Negara Koperasi dan UKM RI Nomor.39/Per/M.KUKM/XII/2007 tentang Pedoman Pengawasan Koperasi Jasa Keuangan Syariah dan Unit Jasa Keuangan Syariah

Undang-undang Nomor 37 Tahun 2004 tentang Kepailitan dan Penundaan Kewajiban Pembayaran Utang (PKPU)

Undang-undang Nomor 17 tahun 2012 tentang Perkoperasian

Undang-undang Nomor 30 Tahun 1999 tentang Arbitrase dan APS

UU Nomor 1 tahun 2013 tentang Lembaga Keuangan Mikro (LKM)

Baitul

Maal

185

JURNAL EKONOMI SYARIAH INDONESIA, Volume II, No.2 Desember 2012 
Thalis

Noor C 